\title{
Environmental and spatial processes determining Ephemeroptera (Insecta) structures in tropical streams
}

\author{
Yulie Shimano $^{1 *}$, Leandro Juen ${ }^{2}$, Frederico Falcão Salles ${ }^{3}$, Denis Silva Nogueira ${ }^{4}$ \\ and Helena Soares Ramos Cabette \\ ${ }^{1}$ Programa de Pós-Graduação em Zoologia, Universidade Federal do Pará, Rua Augusto Correia, no 1 Bairro Guama, 66.075-110, \\ Belém, PA, Brazil \\ 2 Instituto de Ciências Biológicas, Universidade Federal do Pará, Rua Augusto Correia, no 1 Bairro Guamá, 66.075-110, Belém, \\ PA, Brazil \\ 3 Departamento de Ciências Agrárias e Biológicas, Universidade Federal de Espírito Santo, Centro Universitário Norte do Espírito \\ Santo, São Mateus, ES, Brazil \\ 4 Programa de Pós-Graduação em Ecologia e Evolução, Universidade Federal do Goiás, Goiânia, GO, Brazil \\ 5 Departamento de Ciências Biológicas, Universidade do Estado de Mato Grosso, Nova Xavantina, MT, Brazil
}

Received 21 May 2012; Accepted 22 February 2013

\begin{abstract}
Community diversity is expected to reflect variations in local conditions but, recently, ecologists have started to realize that local diversity is also under pressure from global processes. As a result, the traditional view of community structure based on local interspecific interactions was replaced by the idea that community structure is a result of multiple processes acting in different spatial scales. This study is aimed at quantifying the relative importance of spatial, environmental and spatially structured processes on Ephemeroptera community in Cerrado streams in Brazil. Thirty-four rivers and streams in the Brazilian state Mato Grosso were sampled. Ephemeroptera species composition, based on abundance and presence data, was evaluated in relation to niche and neutral predictors by using a partial redundancy analysis (pRDA). Results obtained through the pRDA indicated that both environmental and spatial processes influenced Ephemeroptera abundance. On the other hand, only environmental processes showed effects on community patterns when using species presence data from preserved, altered and large streams and also when looking only at the preserved sites. When streams larger than $20 \mathrm{~m}$ were excluded from analysis, both environmental and spatially processes showed influence on Ephemeroptera composition. Adjusted $R^{2}$ values were higher for environmental than for spatial processes in all analyses. The relatively high influence of both environmental processes and stream width in the analyses highlights the sensitivity of mayflies assemblies to environmental variation, and emphasizes the importance of local processes, as predicted by niche theory, while neutral processes act to a lesser extent on the structure of the studied communities.
\end{abstract}

Key words: Niche theory / neutral theory / environmental variables / aquatic insects / Brazilian streams

\section{Introduction}

The study of species diversity is one of the key topics in community ecology, and its main objective is to find compositive explanations for observed patterns of species abundance and occurrence in space and time (Ricklefs and Schluter, 1993). However, ecological theories have been based almost exclusively on the relationship between community and environment, with species diversity being related to environmental heterogeneity (Popielarz and Neal, 2007). Thus, as a general rule, community diversity is

\footnotetext{
*Corresponding author: yulie.bio@gmail.com
}

expected to reflect variations in local physical and chemical conditions (Ricklefs, 1987). Only recently, ecologists have started to realize that local diversity also reflects pressure from global processes, such as dispersal and particular historical conditions (Ricklefs, 1987). The traditional view of community structure, based on local interspecific interactions and spatial niche, was replaced by more recent ideas emphasizing community structure as a result of multiple processes acting on different spatial scales (Heino et al., 2010).

The main theories in community ecology that aim at explaining species distribution patterns fall into two major groups: niche theories and neutral theories (Scarano and 
Dias, 2004). The ecological niche theory, based on the niche concept of Hutchinson (1957), assumes that the use of resources determines ecological segregation and competition often plays the major role in determining the distribution of species abundance in space and time (Case and Gilpin, 1974). Thus, according to the niche theory, similar environments would present similar species composition in the absence of competition (Chase, 2003; Popielarz and Neal, 2007). According to Rios (2004), the niche theory emerged from the desire to explain why in most communities a large number of species coexist without mutual exclusion, even though many of them use the same resources, and why in these communities some species are abundant, some are common and others, usually the majority, are rare. According to Case (1981), the niche theory has been well accepted, as scientists have been able to determine the most critical and limiting environmental variables for their study organisms (e.g., Corigliano et al., 2001; Buss et al., 2002; Bispo et al., 2006; Cabette et al., 2010).

On the other hand, the unified neutral theory of biodiversity, proposed by Hubbell (2001), predicts that all individuals of any species in a biological community are identical in relation to their probability of reproducing, dying, migrating and speciating. In addition, this theory assumes that communities are saturated, and species abundance cannot increase without the decrease in abundance of other species (De Marco, 2006). Random dispersal of populations is the main feature determining the composition and the structure of ecological communities (Alonso et al., 2006). Thus, it predicts a decrease in similarity of species composition between communities with increasing distance. This decrease in similarity is a function of dispersal abilities, which are spatially limited (Hubbell, 2001). In Hubbell's model, probabilistic processes of colonization and extinction can explain differences in composition and relative species abundance (Cassemiro and Padial, 2008).

The neutral model has changed the classic view of community structure "shaped by niches", which has been intensively studied for decades (Hutchinson, 1957; Austin et al., 1990), to the view of community structure "shaped by dispersion" (Alonso et al., 2006; De Marco, 2006; Adler et al., 2007).

Most studies testing these theories have been carried out with vegetation. However, a few studies have been conducted with aquatic fauna (e.g., Thompson and Towsend, 2006; Vanschoenwinkel et al., 2007). Mayflies (Insecta: Ephemeroptera) are an important component of aquatic systems, as they are abundant in all types of environments, play an important role in nutrient cycling and reflect changes in water quality (McCafferty, 1983; Rosenberg and Resh, 1993). The sensitivity of Ephemeroptera to physical, chemical and physical-chemical changes of an aquatic system has been well described in the literature (e.g.,Brittain, 1982; Salles et al., 2004; Domínguez et al., 2006). Therefore, Ephemeroptera is regarded as a useful research subject in studies with different ecological approaches (e.g., Francischetti et al., 2004; Goulart and
Callisto, 2005; Buss and Salles, 2007; Siegloch et al., 2008; Shimano et al., 2010; Souza et al., 2010). According to Brittain (1982), however, mayflies have limited longdistance dispersal abilities due to their fragile nature and short adult life span, which may effectively contribute to increasing the effect of space in community structuring.

Following the characteristics of Ephemeroptera and the relevance of ecological studies that encompass both niche and neutral theories, this study aims to investigate the importance of environmental processes (niche theory) versus spatial processes (neutral theory) on the structure and composition of Ephemeroptera communities in aquatic ecosystems. It is predicted that both processes will have a similar influence on community structure, due to the sensitivity of Ephemeroptera to environmental variations on the one hand and their low dispersal ability on the other hand.

\section{Methods}

\section{Study site}

Ephemeroptera fauna was measured at 34 sample points. Nine of the sample points were located in Corrente river sub-basin, 13 points were located in the Pindaíba river sub-basin and 12 points in the Suiá-Missu river sub-basin, Mato Grosso State, Brazil (Fig. 1, Table 1).

The Corrente sub-basin flows into the Pindaíba river and is located within the municipality of Barra do Garças. The Pindaíba sub-basin covers parts of the municipalities of Araguaiana, Cocalinho and Nova Xavantina in the South-East of Mato Grosso. According to Rossete (2008), the Corrente and Pindaíba sub-basins constitute the Mortes river basin. Its headwaters are located in highlands of the Guimarães Plateau, which have a average altitude of $600 \mathrm{~m}$, and its course reaches the lowland areas which have an average altitude of $330 \mathrm{~m}$. Owing to the sharp relief on the slopes of the Serra do Roncador, only streams located at lowland areas are affected by human activities. The main economic land uses developed in the region are livestock and, secondarily, cropland (Rossete, 2008). The local climate is classified according to Köppen as Cwa, with two well-defined seasons; dry and rain (Pell et al., 2007). The annual average of precipitation varies between 1200 and $1600 \mathrm{~mm}$ and the temperature varies between 20 and $25^{\circ} \mathrm{C}$ (Brasil, 1983). In the Corrente sub-basin, the samples were collected in the Papagaio (first to fourth order) and Taquaral streams (first to fourth order) and in the Corrente river (fifth order), totaling nine sample points. In the Pindaíba sub-basin, the samples were taken in the Mata (first to fourth order), Cachoeirinha (second to fourth order) and Caveira streams (first to fourth order) and Pindaíba river (fifth and sixth orders), totaling 13 sample points. In all sub-basins, both preserved and altered sites were sampled. Stream orders are based on classification of Strahler (1957). 


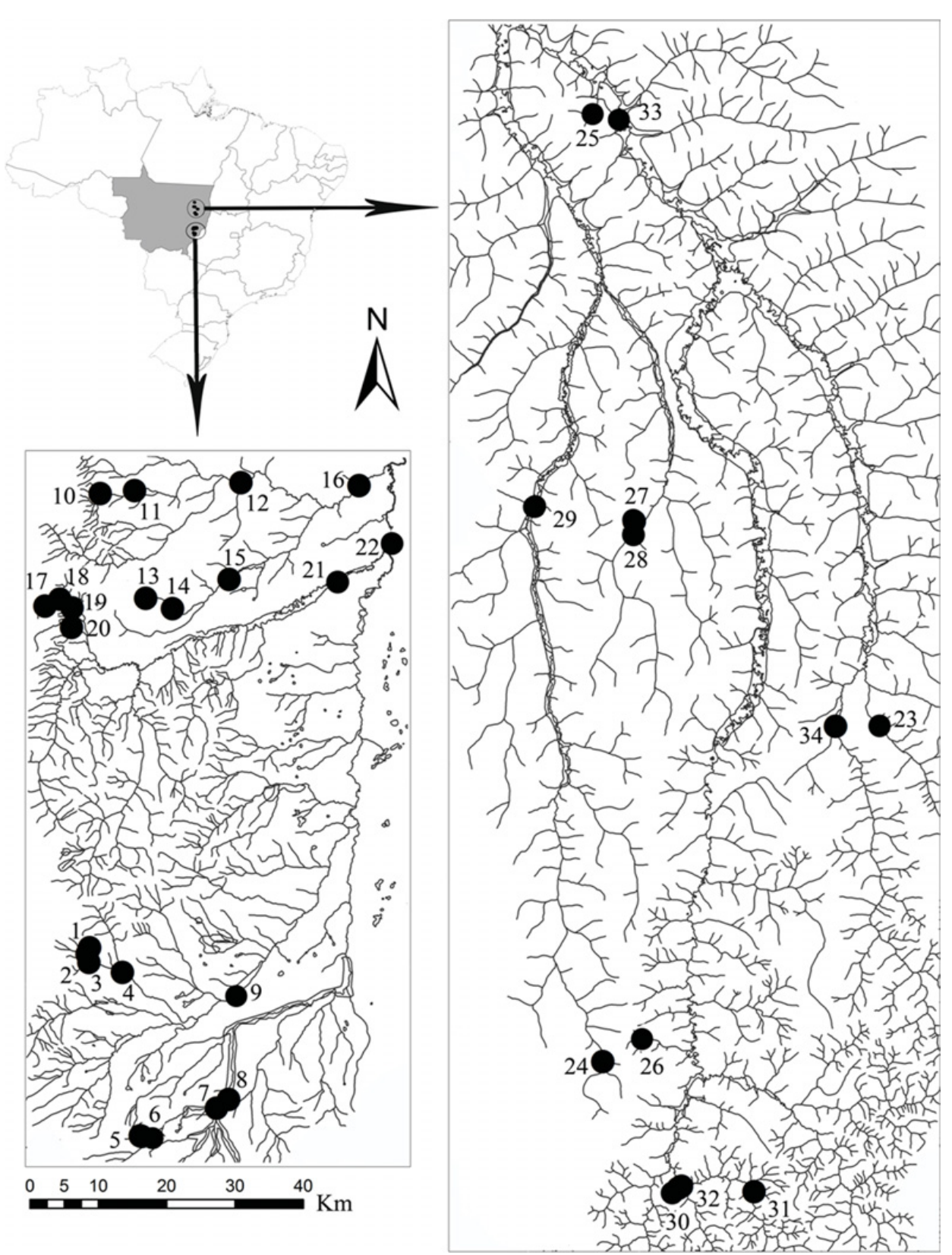

Fig. 1. Location of study sites of Ephemeroptera in eastern region of Mato Grosso State, Brazil, 2005/2008. Left above: Pindaíba river sub-basin; left below: Corrente river sub-basin; right: Suiá-Missu river sub-basin.

The Suiá-Missu sub-basin is located in Central-East Mato Grosso and crosses the municipalities of Querência, Ribeirão Cascalheira and Canarana. This sub-basin is a tributary of the Xingu river basin and is located in the transition zone between the biomes of Amazonia and Cerrado. The main headwaters of the Suiá-Missu river do not fall within the Parque Indígena do Xingu (PIX), and therefore do not fall under its protection. The study region is under strong pressure of agricultural expansion, aggravated by poorly planned rural settlements, leading to direct and indirect effects on conservation areas. The main economic activities in the area are logging, monocultures of rice and soybean, and extensive cattle raising (Schwartzman and Zimmerman, 2005; Hayhoe et al.,
2011). The Suiá-Missu region has a seasonally tropical climate, with a dry period from May to October and a rain period from November to April. The local climate is classified according to Köppen as a savanna subtype ( $A w)$, with microregions of monsoon $(\mathrm{Am})$ and tropical rain (A) subtypes (Ratter et al., 1978; Pell et al., 2007). Average annual precipitation is $1370 \mathrm{~mm}$ and the temperature varies between 17.0 and $32.7^{\circ} \mathrm{C}$ (Marimon et al., 2006).

\section{Methodology and identification}

Samples collected in the Corrente sub-basin, Cachoeirinha stream and Pindaíba river (Pindaíba 
Table 1. Codes and names of studied sites and sub-basins and geographical coordinates of studied sites in eastern region of Mato Grosso State, Brazil, 2005/2008. COB: Corrente river sub-basin; PIB: Pindaíba river sub-basin; SMB: Suiá-Missu river sub-basin.

\begin{tabular}{|c|c|c|c|}
\hline Point & Name of site & Basin & Coordinates \\
\hline$\overline{\text { PT } 01}$ & Papagaio stream - first order & $\mathrm{COB}$ & $15^{\circ} 27^{\prime} 01^{\prime \prime} \mathrm{S}$ and $52^{\circ} 24^{\prime} 30^{\prime \prime} \mathrm{W}$ \\
\hline PT 02 & Papagaio stream - second order & $\mathrm{COB}$ & $15^{\circ} 27^{\prime} 32^{\prime \prime} \mathrm{S}$ and $52^{\circ} 24^{\prime} 42^{\prime \prime} \mathrm{W}$ \\
\hline PT 03 & Papagaio stream - third order & $\mathrm{COB}$ & $15^{\circ} 28^{\prime} 11^{\prime \prime} \mathrm{S}$ and $52^{\circ} 24^{\prime} 32^{\prime \prime} \mathrm{W}$ \\
\hline PT 04 & Papagaio stream - fourth order & $\mathrm{COB}$ & $15^{\circ} 28^{\prime} 56^{\prime \prime} \mathrm{S}$ and $52^{\circ} 21^{\prime} 47^{\prime \prime} \mathrm{W}$ \\
\hline PT 05 & Taquaral stream - first order & $\mathrm{COB}$ & $15^{\circ} 41^{\prime} 54^{\prime \prime} \mathrm{S}$ and $52^{\circ} 20^{\prime} 03^{\prime \prime} \mathrm{W}$ \\
\hline PT 06 & Taquaral stream - second order & $\mathrm{COB}$ & $15^{\circ} 41^{\prime} 57^{\prime \prime} \mathrm{S}$ and $52^{\circ} 19^{\prime} 56^{\prime \prime} \mathrm{W}$ \\
\hline PT 07 & Taquaral stream - third order & COB & $15^{\circ} 39^{\prime} 35^{\prime \prime} \mathrm{S}$ and $52^{\circ} 13^{\prime} 52^{\prime \prime} \mathrm{W}$ \\
\hline PT 08 & Taquaral stream - fourth order & $\mathrm{COB}$ & $15^{\circ} 38^{\prime} 53^{\prime \prime S}$ and $52^{\circ} 12^{\prime} 53^{\prime \prime} \mathrm{W}$ \\
\hline PT 09 & Corrente stream - fifth order & $\mathrm{COB}$ & $15^{\circ} 31^{\prime} 14^{\prime \prime} \mathrm{S}$ and $52^{\circ} 12^{\prime} 10^{\prime \prime} \mathrm{W}$ \\
\hline PT 10 & Cachoeirinha stream - second order & PIB & $14^{\circ} 50^{\prime} 50^{\prime \prime} \mathrm{S}$ and $52^{\circ} 24^{\prime} 22^{\prime \prime} \mathrm{W}$ \\
\hline PT 11 & Cachoeirinha stream - third order & PIB & $14^{\circ} 50^{\prime} 33^{\prime \prime} \mathrm{S}$ and $52^{\circ} 21^{\prime} 34^{\prime \prime} \mathrm{W}$ \\
\hline PT 12 & Cachoeirinha stream - fourth order & PIB & $14^{\circ} 49^{\prime} 45^{\prime \prime} \mathrm{S}$ and $52^{\circ} 12^{\prime} 55^{\prime \prime} \mathrm{W}$ \\
\hline PT 13 & Caveira stream - first order & PIB & $14^{\circ} 59^{\prime} 06^{\prime \prime} \mathrm{S}$ and $52^{\circ} 20^{\prime} 29^{\prime \prime} \mathrm{W}$ \\
\hline PT 14 & Caveira stream - second order & PIB & $14^{\circ} 59^{\prime} 53^{\prime \prime} \mathrm{S}$ and $52^{\circ} 18^{\prime} 17^{\prime \prime} \mathrm{W}$ \\
\hline PT 15 & Caveira stream - third order & PIB & $14^{\circ} 57^{\prime} 28^{\prime \prime} \mathrm{S}$ and $52^{\circ} 13^{\prime} 43^{\prime \prime} \mathrm{W}$ \\
\hline PT 16 & Caveira stream - fourth order & PIB & $14^{\circ} 49^{\prime} 47^{\prime \prime} \mathrm{S}$ and $52^{\circ} 03^{\prime} 16^{\prime \prime} \mathrm{W}$ \\
\hline PT 17 & Mata stream - first order & PIB & $14^{\circ} 59^{\prime} 53^{\prime \prime} \mathrm{S}$ and $52^{\circ} 28^{\prime} 42^{\prime \prime} \mathrm{W}$ \\
\hline PT 18 & Mata stream - second order & PIB & $14^{\circ} 59^{\prime} 18^{\prime \prime} \mathrm{S}$ and $52^{\circ} 27^{\prime} 30^{\prime \prime} \mathrm{W}$ \\
\hline PT 19 & Mata stream - third order & PIB & $14^{\circ} 59^{\prime} 59^{\prime \prime} \mathrm{S}$ and $52^{\circ} 26^{\prime} 29^{\prime \prime} \mathrm{W}$ \\
\hline PT 20 & Mata stream - fourth order & PIB & $15^{\circ} 01^{\prime} 32^{\prime \prime} \mathrm{S}$ and $52^{\circ} 26^{\prime} 29^{\prime \prime} \mathrm{W}$ \\
\hline PT 21 & Pindaíba river - fifth order & PIB & $14^{\circ} 56^{\prime} 56^{\prime \prime} \mathrm{S}$ and $52^{\circ} 04^{\prime} 17^{\prime \prime} \mathrm{W}$ \\
\hline PT 22 & Pindaíba river - sixth order & PIB & $14^{\circ} 54^{\prime} 10^{\prime \prime} \mathrm{S}$ and $52^{\circ} 00^{\prime} 21^{\prime \prime} \mathrm{W}$ \\
\hline PT 23 & Brejão stream & SMB & $12^{\circ} 38^{\prime} 32.3^{\prime \prime S}$ and $51^{\circ} 53^{\prime} 20.6^{\prime \prime} \mathrm{W}$ \\
\hline PT 24 & Lúcio stream & SMB & $13^{\circ} 05^{\prime} 34.5^{\prime \prime} \mathrm{S}$ and $52^{\circ} 15^{\prime} 16.9^{\prime \prime} \mathrm{W}$ \\
\hline PT 25 & Sucuri stream & SMB & $11^{\circ} 49^{\prime} 50.7^{\prime \prime} \mathrm{S}$ and $52^{\circ} 17^{\prime} 02.2^{\prime \prime} \mathrm{W}$ \\
\hline PT 26 & Transição Brejo stream & SMB & $13^{\circ} 03^{\prime} 35.6^{\prime \prime S}$ and $52^{\circ} 12^{\prime} 03.3^{\prime \prime} \mathrm{W}$ \\
\hline PT 27 & Betis river point 1 & SMB & $12^{\circ} 22^{\prime} 28.7^{\prime \prime} \mathrm{S}$ and $52^{\circ} 13^{\prime} 23.1^{\prime \prime} \mathrm{W}$ \\
\hline PT 28 & Betis river point 2 & SMB & $12^{\circ} 22^{\prime} 27.5^{\prime \prime S}$ and $52^{\circ} 13^{\prime} 19.0^{\prime \prime} \mathrm{W}$ \\
\hline PT 29 & Darro river & SMB & $12^{\circ} 21^{\prime} 12.3^{\prime \prime S}$ and $52^{\circ} 21^{\prime} 27.4^{\prime \prime} \mathrm{W}$ \\
\hline PT 30 & Piabanha river & SMB & $13^{\circ} 15^{\prime} 34.4^{\prime \prime S}$ and $52^{\circ} 09^{\prime} 00.5^{\prime \prime} \mathrm{W}$ \\
\hline PT 31 & Suiá-Missu river point 1 & SMB & $13^{\circ} 15^{\prime} 45.5^{\prime \prime} \mathrm{S}$ and $52^{\circ} 02^{\prime} 50.9^{\prime \prime} \mathrm{W}$ \\
\hline PT 32 & Suiá-Missu river point 2 & SMB & $13^{\circ} 15^{\prime} 24.3^{\prime \prime S}$ and $52^{\circ} 08^{\prime} 44.5^{\prime \prime} \mathrm{W}$ \\
\hline PT 33 & Suiá-Missu river point 3 & SMB & $11^{\circ} 50^{\prime} 17.8^{\prime \prime S}$ and $52^{\circ} 15^{\prime} 07.5^{\prime \prime} \mathrm{W}$ \\
\hline PT 34 & Suiazinho river & SMB & $12^{\circ} 38^{\prime} 33.4^{\prime \prime S}$ and $51^{\circ} 56^{\prime} 50.7^{\prime \prime} \mathrm{W}$ \\
\hline
\end{tabular}

sub-basin) were taken in three different seasons; at the peak of the rain season (January 2005), in the dry season (July and August 2005) and at the beginning of the rain period (October and November 2005). The other two streams from Pindaíba sub-basin, da Mata e Caveira, were sampled 2 years later, in the dry season (August 2007), at the beginning of the rainy season (November 2007) and at the peak of the rainy season (January 2008). Finally, the Suiá-Missu sub-basin was sampled during the dry season (September 2007), in the beginning of the rainy period (December 2007) and in the water level dropping period (May 2008).

The methodology used by Cabette et al. (2010), DiasSilva et al. (2010) and Shimano et al. (2010) was used to collect Ephemeroptera nymphs. Fixed transects of $100 \mathrm{~m}$ were delineated and divided into 20 segments of $5 \mathrm{~m}$. Samples were obtained through a sieve of $18 \mathrm{~cm}$ diameter and $0.05 \mathrm{~mm}$ mesh, and were collected three times per segment. In this way, in each stream 20 times three samples were collected. The collected material was sorted in the field and conserved in $85 \%$ alcohol. Ephemeroptera identification was done using identification keys of Domínguez et al. (2006) and Dias et al. (2007). Specimens were deposited at the Zoobotanical Collection "James Alexander Ratter" - CZNX, at Universidade do Estado de Mato Grosso as a reference material.

\section{Environmental variables}

Fourteen environmental variables were measured for the characterization of each sample point. With a portable environmental multiparameter device, measures were taken of water temperature, turbidity, dissolved oxygen, $\mathrm{pH}$ and electric conductivity. Orthophosphate and nitrate concentration were measured with a portable spectrophotometer. Total mineral content and calcium and magnesium concentration were measured using the titulometric method with EDTA 0.0002M.

Average channel width (in meters) was determined through five equidistant measures $(20 \mathrm{~m})$ along the transect using a rangefinder laser. Average channel depth 
(in meters) was calculated for the same points, using three measurements, one in the center and two on opposite sides of the channel. Channel depth was measured using a fiberglass measuring tape or, when necessary, an echo sounder. Environmental integrity of each site was assessed through a habitat integrity protocol, the habitat integrity index (HII), based on Nessimian et al. (2008). The HII consists of 12 questions aimed at measuring changes in environmental complexity. These questions were answered by observing environmental features at each site. HII can vary between 0 and 1 , with larger values indicating higher environmental integrity.

\section{Spatial variables}

A common problem when working with environmental data in order to explain species richness refers to spatial autocorrelation; when data present a strong spatial structure (e.g., residuals are not independent). Therefore, coefficient significance tests are not valid and the estimators do not have minimum variance (Hawkins et al., 2007). Thus, it is necessary to consider that covariance among model residuals is a symptom of a spatial relationship between cells (see Rangel et al., 2006). To avoid this problem, a strategy is to extract eigenvectors from a matrix of geographical distances or connections among spatial units and use them as "filters", in order to reduce residual variation (Borcard and Legendre, 2002; Diniz-Filho and Bini, 2005). To construct the spatial matrix, geographical distances (latitude and longitude) were computed using the software SAM (Spatial Analysis in Macroecology version 4.0) (Rangel et al., 2010), which break down total spatial variation in a number of explanatory spatial variables, each one corresponding to a specific scale or spatial structure. This break down allows a spatial analysis on all scales that can be described by the spatial configuration of sampling sites (Ramette and Tiedje, 2007). Significant eigenvectors with Moran's I coefficients greater than 0.1 were included in the spatial variable matrix, together with latitude and longitude data, to create the spatial distance matrix, which was used in the analyses of variance partitioning as predictors of neutral processes. Geographical coordinates (latitude and longitude) of each sample site were obtained using a GPS.

\section{Data analysis}

To test differences among sub-basins in mayfly abundance, we used an analysis of variance (one-way ANOVA) (Zar, 1990), where the total abundances for each stream were used as replicas for each sub-basin. Assumptions of data normality and homogeneity of variances (Levene's test) were computed and tested. When assumptions were not reached, logarithmic transformations were made. An a posteriori Tukey test was used when ANOVA was significant in order to identify which categories of environmental integrity presented different means.

Species richness among sub-basins was compared using a "momentum-based" rarefaction curve (Mao Tau) (Gotelli and Colwell, 2001), which eliminates the need for replication and allows for a direct comparison of richness among samples. As sub-basins differed with regard to the number of sampled streams, we considered only 540 samples per sub-basin $(20$ segments $\times$ nine streams $\times$ three season $=540$ samples). In the species abundance and richness analyses, the different seasons measured within one year were used as replicates.

A principal coordinates analysis (PCoA) (Legendre and Legendre, 1998) was performed with abundance matrices to examine if the streams are ordered according to their sub-basins and if there are cluster patterns among them. We used logarithmic transformations to reduce the influence of abundant species. Then, to test the significance of clusters established by PCoA, we performed an analysis of similarity (ANOSIM).

To test the relative influence of environmental processes (Niche theory) and of spatial processes (Neutral theory) on the community structure of immature Ephemeroptera, we performed a partial redundancy analysis (pRDA) (Borcard et al., 1992; Legendre and Legendre, 1998). The pRDA results consist of four parts: (a) variation attributed exclusively to environmental variables; (b) shared variation explained by space and environment (spatially structured environmental variation); (c) variation attributed exclusively to spatial variables; and (d) residual variation, which is the non-explained variation (Borcard et al., 1992; Rangel et al., 2010). Specific density data (abundance) were standardized and transformed using Hellinger distance, to preserve the Euclidean distance between sampling units in $n$-dimensional space. This procedure is used if the analyzed data present many zero values, as usually observed in biological matrices (Legendre and Gallagher, 2001). Environmental variable means were computed to the analyses in the three stations, and richness and abundance of all stations were summed up for each sampling point. Significance of eigenvalues of orthogonal axes resulting from the pRDA was tested using a one-way ANOVA. All analyses were performed using $\mathrm{R}$ statistical software ( $\mathrm{R}$ Development Core Team, 2011) labdsv, mgcv and vegan packages.

\section{Tested models}

Due to the large variation among studied streams, three different models were tested in the pRDA analysis. These models were based on the biology of the group. In this way, one model verified all parameters sampled, the second focused on the integrity of the streams (influence of integrity cited by Buss and Salles, 2007; Souza et al., 2010) and the third model emphasized the influence of the large streams (Vannote et al., 1980; Corigliano et al., 2001; Shimano et al., 2010). 
Model A: Data on spatial and environmental parameters of all 34 studied sites were included in the analysis.

Model B: Since sample points differed a lot in relation to habitat integrity, altered sites with HII lower than 0.5 were excluded from the analyses (five streams, with the index of integrity between 0.39 and 0.49 (low integrities); points 23, 25, 26, 29 and 30 see Table 1).

Model C: Sample points broader than $20 \mathrm{~m}$ were excluded from analyses (streams 1, 18, 27, 29, 30 and 33, see Table 1).

\section{Results}

We collected 9450 individuals belonging to eight families, 42 genera and 72 species and/or morphospecies (Appendix 1). Only one family (Oligoneuriidae) of the eight families sampled (Baetidae, Caenidae, Coryphoridae, Euthyplociidae, Leptohyphidae, Leptophlebiidae, Oligoneuriidae and Polymitarcyidae) was not collected in the Suiá-Missu river sub-basin. Others families were present in all sub-basins. Leptophlebiidae was the most abundant in all sub-basins $(n=2451,2593$ and 526 in Corrente, Pindaíba and Suiá-Missu, respectively, totaling 5570 individuals), followed by Baetidae ( $n=907,543$ and 299, respectively, totaling 1749 individuals). The most abundant morphotypes were Miroculis sp. $(n=2248)$, Farrodes sp. $(n=1114)$ and Terpides sooretamae Boldrini and Salles, $2009(n=865)$ (Leptophlebiidae) in Corrente and Pindaíba sub-basins. Suiá-Missu sub-basin showed Fittkaulus cururuensis Savage, 1986 $(n=312)$, Caenis cuniana Froehlich, $1969 \quad(n=160)$ (Leptophlebiidae) and Callibaetis sp. $2(n=116)$ (Baetidae) as the most abundant species. Coryphoridae and Oligoneuriidae were the least abundant families, with 18 and 31 individuals, respectively. Harpagobaetis gulosus Mol, 1986, Tricorythopsis baptistai Dias and Salles, 2005, Tricorythopsis bahiensis Dias, Salles and Ferreira, 2008, Tikuna bilineata (Neddham and Murphy, 1924) and Tortopsis sp.1 were represented by only one individual.

\section{Abundance and richness of sub-basins}

The Corrente sub-basin showed the highest abundance ( $n=4252)$, followed by Pindaíba sub-basin $(n=3845)$ and Suiá-Missu $(n=1353)$. However, statistical tests showed only that Corrente sub-basin was significantly different from Suiá-Missu sub-basin $\left(F_{(2,31)}=6.338, p=0.004\right.$, Tukey $p<0.05)$. The Pindaíba sub-basin showed the highest richness, with 56 species/morphospecies, while Suiá-Missu and Corrente sub-basins contained 46 species/ morphospecies. Estimated richness based on 540 samples (for sub-basins) showed Pindaíba sub-basin as the richest in species $(53.02 \pm 1.88$; mean \pm confidence interval), followed by Corrente sub-basin $(48.0 \pm 2.03)$ and Suiá-Missu sub-basin $(44.48 \pm 1.74)$.

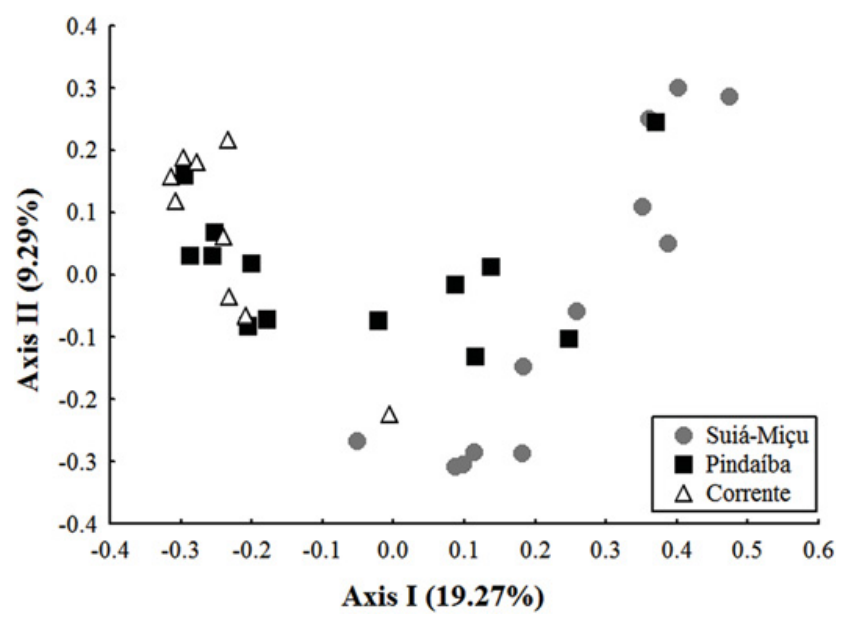

Fig. 2. Ordination of sites of Suiá-Missu, Corrente and Pindaíba river sub-basins generated by a Principal coordinates analysis with species abundance data of Ephemeroptera communities, 2005/2008.

\section{Species composition}

When streams were ordered according to abundance and species composition, PCoA showed that the Corrente streams formed a group aligned in the left of diagram. Suiá-Missu streams, despite being more dispersed in the graph, are mainly concentrated on the right of diagram. Finally, the Pindaíba streams were dispersed all over the graph (Fig. 2). The ANOSIM results confirmed the difference between Suiá-Missu and the other two sub-basin compositions (Corrente: $R=0.539$ and $p=0.001$; Pindaíba: $R=0.207$ and $p=0.008$ ), and showed that Corrente and Pindaíba streams were similar in their composition $(R=-0.020$ and $p=0.590)$.

\section{Niche and neutral components}

The different models tested (A, B and C) based on abundance data were significant for both environmental filters and spatial eigenvectors in partial RDA (Table 2). However, environmental filters produced higher adjusted $R^{2}$ values than spatial filters, indicating the influence of environmental features in species composition of Ephemeroptera. Using presence data, only in model C did both environmental and spatial filters significantly explain the variation in species composition.

Variation of community structure explained by spatially structured environmental variation in the spatial gradient was higher than variation purely explained by spatial filters in models A and B. Spatial structure in environmental variables is, in part, related to spatial autocorrelation, which was significant according to Moran's $I$ coefficient $(p / k<0.05)$ for distances smaller than $100 \mathrm{~km}$. Despite the significance of environmental and spatial processes in species composition variation, much of the proportion explained by pRDA, regardless of model type and data used (presence or abundance), and was retained 
Table 2. Results of RDA from Ephemeroptera abundance and incidence data in streams and rivers of Corrente, Pindaíba e SuiáMissu sub-basins, Mato Grosso State, Brasil, 2005/2008. Significant results are in bold. Model A: with all streams; model B: streams with HII larger than 0.05 and model C: streams with width smaller than $20 \mathrm{~m}$. [a] is the effect attributed only to environmental variables; [b] is the effect attributed to both spatial and environmental variables; [c] is the effect attributed only to spatial variables; and $[\mathrm{d}]$ is the residual.

\begin{tabular}{|c|c|c|c|c|c|c|}
\hline & \multicolumn{2}{|c|}{$\begin{array}{c}\text { All streams } \\
\text { Model A }\end{array}$} & \multicolumn{2}{|c|}{$\begin{array}{l}\text { HII }>0.5 \\
\text { Model B }\end{array}$} & \multicolumn{2}{|c|}{$\begin{array}{c}\text { Width }<20 \mathrm{~m} \\
\text { Model C }\end{array}$} \\
\hline & Adjusted $R^{2}$ & $P$ & Adjusted $R^{2}$ & $P$ & Adjusted $R^{2}$ & $P$ \\
\hline \multicolumn{7}{|l|}{ Abundance } \\
\hline [a] & 0.187 & $>0.001$ & 0.234 & $>0.001$ & 0.280 & $>0.001$ \\
\hline [b] & 0.141 & & 0.099 & & 0.068 & \\
\hline [c] & 0.058 & 0.016 & 0.087 & 0.031 & 0.109 & 0.012 \\
\hline [d] & 0.611 & & 0.579 & & 0.541 & \\
\hline \multicolumn{7}{|l|}{ Incidence } \\
\hline [a] & 0.126 & $>0.001$ & 0.165 & $>0.001$ & 0.194 & 0.004 \\
\hline [b] & 0.114 & & 0.104 & & 0.046 & \\
\hline [c] & 0.033 & 0.062 & 0.047 & 0.102 & 0.098 & 0.014 \\
\hline [d] & 0.725 & & 0.682 & & 0.660 & \\
\hline
\end{tabular}

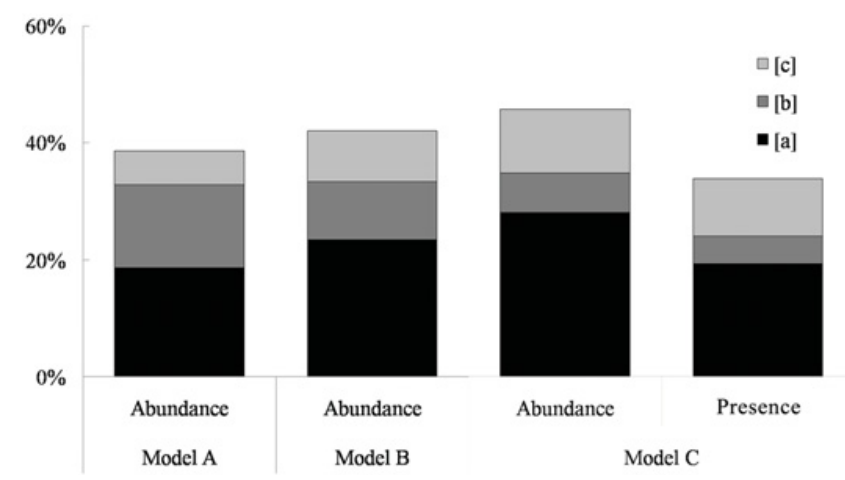

Fig. 3. Variance partitioning of [a] exclusively environmental process, [b] spatially structured environmental process, [c] exclusively spatial process and [d] not explained residual variation of Ephemeroptera communities in rivers and streams from eastern region of Mato Grosso State, Brazil, 2005/2008. Only significant results are represented from model A (all sites with abundance data); model B (sites with $\mathrm{HII}>0.50$ and abundance data) and model $\mathrm{C}$ (sites with width larger than 20 m excluded).

in residuals (between 54.1 and $72.5 \%$ of residual variation). Analyses based on abundance data were more robust; the non-explained variation (residuals) was lower than that observed by using presence data. Nevertheless, regardless of data used (abundance or presence), there was a lower percentage of variation explained in the model in which sample sites with streams broader than $20 \mathrm{~m}$ were excluded from the analysis (model C), with coefficients of variation being larger for both environmental and spatial variables (Fig. 3).

\section{Discussion}

\section{Abundance and richness in the sub-basins}

It is likely that persistent and intense disturbances occurring in the Suiá-Missu river sub-basin are the main cause of low abundance within this sub-basin compared to Corrente and Pindaíba sub-basins. According to the neutral theory of biodiversity, population dynamics are guided by temporal sequences of movements of individuals that die at each time period (Cassemiro and Padial, 2008), and disturbances are the main cause of these dynamics. As an alternative, niche-based models predict that abundances change in a rapid and predictable way in response to environmental changes (Chave, 2004). When the environment changes, differences in a species niche may cause changes in individual fitness and population demography, resulting in deterministic changes in abundance and species composition (Chave, 2004).

In addition, according to niche theory, species richness would increase with an increase of diversity of conditions in a given site. Thus, it would be expected that as local conditions deviate further from normal conditions (optimum for most of the species), the number of species that occur in that site will be less and the number of individuals per species in that site will be higher (Vison and Hawkins, 1998). The higher richness observed in the Pindaíba subbasin can be attributed to the fact that this sub-basin contains, at the same time, sections of very preserved and very altered habitats, with HII values varying from 0.43 to 0.97 (range of variation of 0.53 ). This higher richness could also be related to the availability of environments of varying sizes (first to sixth order). This could allow for the occurrence of a larger number of species because of the spatial difference in ecological niches along the rivers' continuum. The Suiá-Missu river sub-basin showed a range of variation of only 0.34 among more preserved and more altered environments and Corrente river sub-basin showed a value of 0.35 . Thus, by the combined occurrence of species present in very impacted streams (generalists) and species present in preserved sites (specialists), it can be expected that regional richness tends to be higher. Despite little variation in integrity, features such as the presence of flood and semi-lentic environments in the Suiá-Missu river sub-basin and the smaller size and lower number of sampled points in Corrente river sub-basin cannot be 
rejected as possible explanations of lower richness in these sites.

\section{Species composition}

The difference in species composition in Suiá-Missu river sub-basin can be a result of the connectivity between Corrente and Pindaíba sub-basins, which can facilitate species dispersal by drift downstream or by migrations upstream in the mating and oviposition period (nuptial flight) (Sode and Wiberg-Larsen, 1993; Kovats et al., 1996). Thus, the larger the connectivity among sub-basins, the larger the number of species shared, increasing the importance of marginal vegetation conservation to biodiversity.

Moreover, the Suiá-Missu river sub-basin, which is part of the Amazon Basin, differs considerably from the other sub-basins. The Suiá-Missu river has, on average, lower $\mathrm{pH}$, higher turbidity, lower conductivity and higher hardness of the water. Moreover, at the Suiá-Missu subbasin, a higher number of sites that were flooded, had a broader stream or had a higher light input in the headwaters that were sampled, this was due to the difficulty to find smaller undisturbed environments. Amazonian streams are often structurally different, they originate usually in flat areas and are more susceptible to flooding than Cerrado streams, with less currents and more acidic waters. The streams studied in the Cerrado region have their headwaters in steep areas at Serra do Roncador, are deeper and have a larger water flow (Dias-Silva et al., 2010; Shimano et al., 2010). The speed of water flow is known to be one feature that causes variation in species composition of Ephemeroptera in the region (Shimano et al., 2010). Thus, variation in environmental structure can explain the observed differences in species composition showed by DCA in this study.

\section{Niche and neutral components}

According to Vergnon et al. (2009), current ecological models suggest that high diversity can be generated exclusively by niche processes, by neutral processes, or by a combination of ecological processes based on local and regional or spatial environmental features. As observed in this study, community composition of Ephemeroptera can be explained by local environmental features as well as by spatial features. Moreover, much of the proportion explained by variance partitioning in the analyzed models in pRDA was related to the effect of a spatial gradient of environmental variables on species composition. This effect can be related, in part, to the spatial autocorrelation of the spatial units within the sub-basins, as many of the sampled sites represent the longitudinal configuration of rivers, from headwaters to the larger portions of the river. The occurrence of positive spatial autocorrelation can be a result of the effects of biological features, such as dispersal ability, on composition and local abundance pattern of species, as verified in other studies (Lloyde et al., 2005, 2006).

The influence of both environmental and spatial processes on Ephemeroptera communities suggests that dispersal mechanisms, as well as mass effects and sorting species shape the structure of these communities. This pattern was verified in $29 \%$ of the studies, according to a meta-analysis carried out by Cottenie (2005). However, the predominance of exclusively environmental and exclusively spatial processes in the structure of the studied communities may be partially due to the number of spatial variables and the type of distance matrix used in the analyses. As recently demonstrated by Landeiro et al. (2011), these features strongly affect the results of metacommunity models and can confound interpretation of the results. Despite this problem, for aquatic insects, which are able to migrate by the water course by drift and through movements by land at periods of emergence and mating of adults, the type of distance matrix seems to affect the results but little (Landeiro et al., 2011). Heino (2005), studying functional biodiversity of macroinvertebrate assemblages along major ecological gradients of boreal headwater streams, also found that both processes, environmental and spatial gradients, are related to functional richness, functional diversity and functional evenness.

Our results support the ideas of Chase and Leibold (2003), who believe that the truth should be found somewhere between the extremes of the two theories, as well as the ideas of Adler et al. (2007), who argue that each theory strengthens the knowledge of the other. Gravel et al. (2006) proposed the "continuum hypothesis", in which the two theories are linked together to form a continuum from competitive to stochastic exclusion.

Although the neutral model has reproduced fundamental ecological patterns and many recent studies have found that abundance distribution patterns are better explained based on the neutral model than based on niche theory (e.g., Volkov et al., 2003; McGill et al., 2006), Adler et al. (2007) argue that few studies have been successful in quantifying the importance of niches for the preservation of diversity in natural systems. However, according to the results presented in this study, for Ephemeroptera community, the niche-based model was the best predictor of variations in abundance distribution pattern of species (structure) and of faunistic composition (presence data).

The higher percentage of variation in Ephemeroptera community structures explained by environmental factors could be due to the high sensitivity of the taxa to many contaminants (Clements et al., 2002) and to physical changes of the system (Buss et al., 2002; Shimano et al., 2010). In addition, there are also reports of the influence of temperature, substrate type and speed of water flow on Ephemeroptera (Brittain, 1982). According to Ricklefs (1987), there is an influence of local attributes on local diversity. If local conditions determine local diversity, then variations in regional diversity would have some influence on local diversity, through species turnover 
along geographical and ecological gradients. This could explain discrepancies between local and regional diversities.

Vieira (2008, unpublished thesis), studying a zooplankton community in a floodplain of the Araguaia river, also found an influence of environmental and spatial variables, without differences between these variables in relation to percentage of variation explained in community structure. Sattler et al. (2010), studying three different communities (spiders, bees and birds), and Nogueira et al. (2011, unpublished thesis), for Trichoptera at the same sub-basins of this study (Corrente, Pindaíba and Suiá-Missu), found effects only of environmental variables. On the other hand, Heino et al. (2003) have studied macroinvertebrate diversity and have found only influence of spatial variables, further suggesting the abandonment of the traditional local approach, and suggesting processes "within" streams as sole or primary regulators of local diversity.

Percentages of explained variation of neutral and niche processes were influenced by stream size, indicating that very large sites have different composition and structure than smaller streams. According to the River Continuum Concept, proposed by Vannote et al. (1980), distributions of species and trophic guilds in the aquatic communities are organized according to energy flow of the environment, with narrow stream environments (headwaters), intermediate and wide stream environments differing in the amount of allochthonous and autochthonous matter and in the particle size of available organic matter. Several authors report the influence of stream size on aquatic communities (e.g., Heino et al., 2005; Paller et al., 2006). Shimano et al. (2010) point out the importance of width and water flow (lothic/lentic) of habitats on species composition of Ephemeroptera. The distinct species composition of Suiá-Missu river sub-basin supports this idea, this sub-basin had the highest number of sites with a stream width larger than $20 \mathrm{~m}$ (excluded in model C), with some sites even wider than $100 \mathrm{~m}$.

A spatially structured environmental variation higher than purely spatial variation, as seen in models A and B, indicates that the environmental variables analyzed were spatially structured (Vieira, 2008, unpublished data). This was not the case when wide streams were excluded from the analyses (model C). However, purely environmental variation continues to explain a higher proportion of variation than the other theories.

The high percentage of residual variation indicates that important features in structuring communities may not have been measured, or even that more complex processes are at work. For example, Poff et al. (1991) address the importance of hydrological features. Vison and Hawkins (1998) argue that richness patterns reflect substrate size, disturbance regime, predation, annual temperature changes, intermittence and biome type. For the niche theory, interspecific competition has been considered to be one of the main factors of community structure and species composition. Moreover, historical factors, such as the order of species arriving in the environment, cannot be discarded (Chase, 2003). Studies performed on other organisms (spiders, birds, bees, caddisflies and zooplankton) also reported a high percentage of variance left unexplained, of up to $95 \%$ (Vieira, 2008, unpublished data; Sattler et al., 2010; Nogueira et al., 2011, unpublished data).

Thus, we may conclude that, despite spatial processes being structuring agents of composition and distribution of species of Ephemeroptera, environmental processes were more important. Hence, this study once again adds plausible arguments to the importance of Ephemeroptera to biomonitoring and water quality studies. Next steps in ecological studies of this group should include efforts to further understand what are the key environmental variables structuring these communities.

Acknowledgements. We would like to express our thanks to Herson Lima, Lorivaldo Castro and the people of Entomology laboratory of Universidade do Estado de Mato Grosso, Nova Xavantina, by helping with samplings. To Ully Matilde Pozzobom, for the limnological analyses and Mariana Pavan, Hilton Marcelo Lima Souza and Leandro Brasil for helping with the identification of collected material. To Fábio M.V. Carvalho and Anna Duden from 33 Forest for the contributions in the translation of the manuscript. To CNPq, process number proc. no 520268/2005-9 and proc. no 306670/2012-7, PROBIO/MMA, proc. no 680020/02-0 and FAPEMAT, proc. no 098/2004 and $0907 / 2006$ for supporting us with grants for projects.

\section{References}

Adler P.B., HilleRisLambers J. and Levine J.M., 2007. A niche for neutrality. Ecol. Lett., 10, 95-104.

Alonso D., Etienne R.S. and Mckane A.J., 2006. The merits of neutral theory. Tree, 21, 451-457.

Austin M.P., Nicholls A.O. and Margules C.R., 1990. Measurement of the realized qualitative niche: environmental niches of five eucalyptus species. Ecol. Monogr., 60, 161-177.

Bispo P.C., Oliveira L.G., Bini L.M. and Souza K.D., 2006. Ephemeroptera, Plecoptera and Trichoptera assemblages from riffles in mountain streams of centralBrazil: environmental factors influencing the distribution and abundance of immature. Braz. J. Biol., 66, 611-622.

Borcard D. and Legendre P., 2002. All-scale spatial analysis of ecological data by means of principal coordinates of neighbor matrices. Ecol. Model., 153, 51-68.

Borcard D., Legendre P. and Drapeau P., 1992. Partialling out the spatial component of ecological variation. Ecology, 73, 1045-1055.

Brasil, 1983. Projeto RADAMBRASIL, Folha SD 22. Goiás: geologia, geomorfologia, pedologia, vegetação, uso potencial da terra. Ministério das Minas e Energia/Divisão de Publicação.

Brittain J.E., 1982. Biology of mayflies. Annu. Rev. Entomol., 27, 119-147.

Buss D.F. and Salles F.F., 2007. Using Baetidae species as biological indicators of environmental degradation in a Brazilian river basin. Environ. Monit. Assess., 130, 365-372.

Buss D.F., Baptista D.F., Silveira M.P., Nessimian J.L. and Dorvillé L.F.M., 2002. Influence of water chemistry and 
environmental degradation on macroinvertebrate assemblages in a river basin in south-eastBrazil. Hydrobiologia, 481, 125-136.

Cabette H.S.R., Giehl N.F., Dias-Silva K., Luen L. and Batista, J.D., 2010. Distribuição de Nepomorpha e Gerromorpha (Insecta: Heteroptera) da Bacia Hidrográfica do Rio SuiáMiçu, MT: Riqueza relacionada à qualidade do hábitat. In: Santos J.E., Galbiati C. and Moschini L.E. (eds.), Gestão e educação ambiental, água, biodiversidade e cultura, Rima, São Carlos, 113-137.

Case T.J., 1981. Niche packing and coevolution in competition communities. Proc. Natl. Acad. Sci. U.S.A., 78, 5021-5025.

Case T.J. and Gilpin M.E., 1974. Interference competition and Niche theory. Proc. Natl. Acad. Sci. U.S.A., 71, 3073-3077.

Cassemiro F.A.Z. and Padial A.A., 2008. Teoria Neutra da Biodiversidade e biogeografia: aspectos teóricos, impactos na literatura e perspectivas. Oecol. Bras., 12, 706-719.

Chase J.M., 2003. Community assembly: when should history matter? Oecologia, 136, 489-498.

Chave J., 2004. Neutral theory and community ecology. Ecol. Lett., 7, 241-253.

Clements W.H., Carlise D.M., Courtney L.A. and Harrahy E.A., 2002. Integrating observational and experimental approaches to demonstrate causation in stream biomonitoring studies. Environ. Toxicol. Chem., 21, 1138-1146.

Corigliano M.C., Gualdoni C.M., Oberto A.M. and Raffaini G.B., 2001. Longitudinal distribution of the mayfly (Ephemeroptera) communities at the Chocancharava River Basin (Córdoba, Argentina). In: Dominguez E. (ed.), Trends in Research in Ephemeroptera and Plecoptera, Kluwer Academic/plenum Publishers, Tucuman, 89-95.

De Marco P., 2006. Um longo caminho até uma teoria unificada para a ecologia. Oecol. Bras., 10, 120-126.

Dias L.G., Molineri C. and Ferreira P.S.F., 2007. Ephemerelloidea (Insecta: Ephemeroptera) do Brasil. Pap. Avulsos de Zool., 47, 213-244.

Dias-Silva K., Cabette H.S.R., Juen L. and De Marco P., 2010. The influence of habitat integrity and physical-chemical water variables on the structure of aquatic and semi-aquatic Heteroptera. Zoologia, 27, 918-930.

Diniz-Filho J.A.F. and Bini L.M., 2005. Modelling geographical patterns in species richness using eigenvector-based spatial filters. Global Ecol. Biogeogr., 14, 177-185.

Domínguez E., Molineri C., Pescador M.L., Hubbard M. and Nieto C., 2006. Ephemeroptera of South America. Pensoft, Moscow, 646.

Francischetti C.N., Da-Silva E.R., Salles F.F. and Nessimian, J.L., 2004. A ephemeropterofauna (Insecta: Ephemeroptera) do trecho ritral inferior do Rio Campo Belo, Itatiaia, RJ: composição e mesodistribuição. Lundiana, $5,33-39$.

Gauch H.G., 1982. Multivariate Analysis in Community Ecology, Cambridge University Press, Cambridge.

Gotelli N.J., Colwell R.K., 2001. Quantifying biodiversity: procedures and pitfalls in the measurement and comparison of species richness. Ecol. Lett., 4, 379-391.

Goulart M. and Callisto M., 2005. Mayfly diversity in the Brazilian tropical headwaters of Serra do Cipó. Braz. Arch. Biol. Technol., 48, 983-996.

Gravel D., Canham C.D., Beaudet M. and Messier C., 2006. Reconciling niche and neutrality: the continuum hypothesis. Ecol. Lett., 9, 399-409.
Hawkins B.A., Diniz-Filho J.A.F., Jaramillo C.A. and Soeller S.A., 2007. Climate, niche conservatism, and the global bird diversity gradient. Am. Nat., 170, 16-27.

Hayhoe S.J., Neill C., Porder S., McHorney R., Lefebvre P., Coe M.T., Elsenbeer, H. and Krusche, V. 2011. Conversion to soy on the Amazonian agricultural frontier increases streamflow without affecting stormflow dynamics. Global Change Biol., 17, 1821-1833.

Heino, J., 2005. Functional biodiversity of macroinvertebrate assemblages along major ecological gradients of boreal headwater streams. J. Freshwater Biol., 50, 1578-1587.

Heino J., Muotka T. and Paavola R., 2003. Determinants of macroinvertebrate diversity in headwater streams: regional and local influences. J. Anim. Ecol, 72, 425-434.

Heino J., Parviainen J., Paavola R., Jehle M., Louhi P. and Muotka T., 2005. Characterizing macroinvertebrate assemblage structure in relation to stream size and tributary position. Hydrobiologia, 539, 121-130.

Heino J., Bini L.M., Karjalainen S.M., Mykra H., Soininen J., Vieira L.C.G. and Diniz-Filho J.A.F., 2010. Geographical patterns of micro-organismal community structure: are diatom ubiquitously distributed across boreal streams? Oikos, 119, 129-137.

Hill M.O. and Gauch H.G., 1980. Detrended correspondence analysis, an improved ordination technique. Vegetation, 42, 47-58.

Hubbell S.P., 2001. The unified neutral theory of Biodiversity and Biogeography, Princeton University Press, Princeton, $448 \mathrm{p}$.

Hutchinson G.E., 1957. Population studies - animal ecology and demography: concluding remarks. Cold Spring Harbor Symp. Quant. Biol., 22, 415-427.

Kovats Z.E., Ciborowsky J.J.H. and Corkum L.D., 1996. Inland dispersal of adult aquatic insects. Freshwater Biol., 36, 265-276.

Landeiro V.L., Magnusson W.E., Melo A.S., EspíritoSanto H.M.V., Bini L.M., 2011. Spatial eigenfunction analyses in stream networks: do watercourse and overland distances produce different result?Freshwater Biol., 56, 1184-1192.

Legendre P. and Gallagher E.D., 2001. Ecologically meaningful transformations for ordination of species data. Oecologia, 129, 271-280.

Legendre P. and Legendre L., 1998. Numerical Ecology, Elsevier Science B.V., Amsterdam, 853 p.

Lloyde N.J., MacNally R. and Lake P.S., 2005. Spatial autocorrelation of assemblages of benthic invertebrates and its relationship to environmental factors in two upland rivers in southeastern Australia. Divers. Distrib., 11, 375-386.

Lloyde N.J., Mac Nally R., Lake P.S., 2006. Spatial scale of autocorrelation of assemblages of benthic invertebrates in two upland rivers in South-eastern Australia and its implications for biomonitoring and impact assessment in streams. Environ. Monit. Assess., 115, 69-85.

Marimon B.S., Lima E.S., Duarte T.G., Chieregatto L.C. and Ratter J.A., 2006. Observations on the vegetation of northearstern Mato Grosso, Brazil. IV. An analysis of the Cerrado-Amazonian Forest Ecotone. Edin. J. Bot., 63, 323-341.

McCafferty W.P., 1983. Aquatic entomology: the Fishermen's and Ecologists' Illustrated Guide Insects and their Relatives, Jones and Bartlett Publishers, London. 
McGill B.J., Maurer B.A. and Weiser M.D., 2006. Empirical evaluation of neutral theoretical. Ecology, 87, 1411-1423.

Nessimian J.L., Venticinque E.M., Zuanon J., De Marco P., Gordo M., Fidelis L., Batista J.D. and Juen L., 2008. Land use, habitat integrity, and aquatic insect assemblages in Central Amazonian streams. Hydrobiologia, 10.1007, $1-12$.

Paller M.H., Specht W.L. and Dyer S.A., 2006. Effects of stream size on taxa richness and other commonly used benthic bioassessment metrics. Hydrobiologia, 568, 309-316.

Pell M.C., Finlayson B.L. and McMahon T.A., 2007. Updated world map of the Köppen-Geiger climate classification. Hydrol. Earth Syst. Sci., 11, 1633-1644.

Poff N.L., DeCino R.D. and Ward J.V., 1991. Size-dependent drift responses of mayflies to experimental hydrologic variation: active predator avoidance of passive hydrodynamic displacement?Oecologia, 88, 577-586.

Popielarz P.A. and Neal Z.P., 2007. The niche as a theoretical toll. Annu. Rev. Sociol., 33, 65-84.

Ramette A. and Tiedje J.M., 2007. Multiscale responses of microbial life to spatial distance and environmental heterogeneity in a patchy ecosystem. Proc. Natl. Acad. Sci. U.S.A., 104, 2761-2766.

Rangel T.F.L.B., Diniz-Filho J.A.F. and Bini L.M., 2006. Towards an integrated computational tool for spatial analysis in macroecology and biogeography. Global Ecol. Biogeogr., 15, 321-327.

Rangel T.F.L.V.B., Diniz-Filho J.A.F. and Bini L.M., 2010. SAM: a comprehensive application for Spatial Analysis in Macroecology. Ecography, 33, 46-50.

Ratter J.A., Askew G.P., Montgomery R.F. and Gifford D.R., 1978. Observations on the vegetation of northeastern Mato Grosso II.Forest and Soils of the Rio Suiá-Miçu area. Proc. R. Soc. Lond. B Biol. Sci., 293, 191-208.

Ricklefs R.E., 1987. Community diversity: relative roles of local and regional processes. Science, 235, 167-171.

Ricklefs R.E. and Schluter D., 1993. Species diversity: regional and historical influences. In: Ricklefs R.E. and Schluter D. (eds.), Species Diversity in Ecological Communities, University of Chicago Press, Chicago, 350-363.

Rios R.I., 2004. A Teoria do Nicho Ecológico: Benefícios e malefícios. In: Coelho A.S., Loyola R.D. and Souza M.B.G. (eds.), Ecologia teórica: desafios para o aperfeiçoamento da ecologia no Brasil, O lutador, Belo Horizonte, 24-44.

Rosenberg D.M. and Resh V.H., 1993. Introduction to freshwater biomonitoring and benthic macroinvertebrates. In: Rosenberg D.M. and Resh V.H. (eds.), Freshwater biomonitoring and benthic macroinvertebrates, Chapman and Hall, New York, 1-9.

Rossete A.N., 2008. Componente: meio físico e uso atual da terra. In: Cabette H.S.R. (ed.), Uso de indicadores ambientais na gestão de recursos hídricos na Bacia Hidrográfica do Rio Pindaíba - MT, Editora Unemat, Nova Xavantina, 1-21.
Salles F.F., Da-Silva E.R., Hubbard M.D. and Serrão J.E., 2004. As espécies de Ephemeroptera (Insecta) registradas para o Brasil. Biota Neotrop., 4, 1-34.

Sattler T., Borcard D., Arlettaz R., Bontadina F., Legendre P., Obrist M.K., Morreti M., 2010. Spider, bee, and bird communities in cities are shaped by environmental control and high stochasticity. Ecology, 91, 3343-3353.

Scarano F.R. and Dias A.T., 2004. A importância de espécies no funcionamento de comunidades e ecossistemas. In: Coelho A.S., Loyola R.D. and Souza M.B.G. (eds.), Ecologia teórica: desafios para o aperfeiçoamento da ecologia no Brasil, O Lutador, Belo Horizonte, 32-46.

Schwartzman S. and Zimmerman B., 2005. Conservation alliances with indigenous people of the Amazon. Conserv. Biol., 19, 721-727.

Shimano Y., Cabette H.S.R., Salles F.F. and Juen L., 2010. Composição e distribuição da fauna de Ephemeroptera (Insecta) em áreas de transição Cerrado-Amazônia, Brasil. Iheringia, 100, 1-8.

Siegloch A.E., Froehlich C.G. and Kotzian C.B., 2008. Composition and diversity of Ephemeroptera (Insecta) nymph communities in the middle section of the Jacuí River and some tributaries, southern Brazil. Iheringia, 98, 425-432.

Sode A. and Wiberg-Larsen P., 1993. Dispersal of adult Trichoptera at a Danish forest brook. Freshwater Biol., 30, 439-446.

Souza H.M.L., Juen L. and Cabette H.S.R., 2010. Diversidade beta de Baetidae (Ephemeroptera) em córregos da Bacia Hidrográfica do Rio Pindaíba (MT). In: Santos J.E., Galbiati C. and Moschini L.E. (eds.), Gestão e educação ambiental, água, biodiversidade e cultura, Rima, São Carlos, 109-123.

Strahler H.N., 1957. Quantitative analysis of watershed geomorphology. Am. Geophys. Union, 38, 913-920.

Thompson R. and Towsend C., 2006. A truce with neutral theory: local deterministic factors, species traits and dispersal limitation together determine patterns of diversity in streams invertebrates. J. Anim. Ecol., 75, 476-484.

Vannote R.L., Minshall G.W., Cummins K.W., Sedell J.R. and Cushing C.E., 1980. The river continuum concept. Can. J. Fish. Aquat. Sci., 37, 130-137.

Vanschoenwinkel B., De Vries C., Seaman M. and Brendonck L., 2007. The role of metacommunity processes in shaping invertebrate rock pool communities along a dispersal gradient. Oikos, 116, 1255-1266.

Vergnon R., Dulvy N.K. and Freckleton R.P., 2009. Niches versus neutrality: uncovering the drivers of diversity in a species-rich community. Ecol. Lett., 12, 1079-1090.

Vison M.R. and Hawkins C.P., 1998. Biodiversity of stream insects: variation at local, basin and regional scales. Annu. Rev. Entomol., 43, 271-193.

Volkov I., Banavar J.R., Hubbell S.P. and Maritan A., 2003. Neutral theory and relative species abundance in ecology. Nature, 424, 1035-1037.

Zar J.H., 1990. Biostatistical analysis. Prentice-Hall, New York, $944 \mathrm{p}$. 